\title{
Determinants of Exclusive Breastfeeding: A Cross Sectional Study in the Work Area of Bulili Public Health Center in South Palu, Palu City
}

\author{
Muhammad Rizki Ashari ${ }^{1 *}$, Nur Asri Zuhria ${ }^{1}$, Bambang Dwicahya ${ }^{2}$ (D) \\ ${ }^{1}$ Department of Health Administration and Policy, Faculty of Public Health, Tadulako University, Palu, Indonesia; ${ }^{2}$ Departement \\ of Environmental Health, Faculty of Public Health, Tompotika University, Central Sulawesi, Indonesia
}

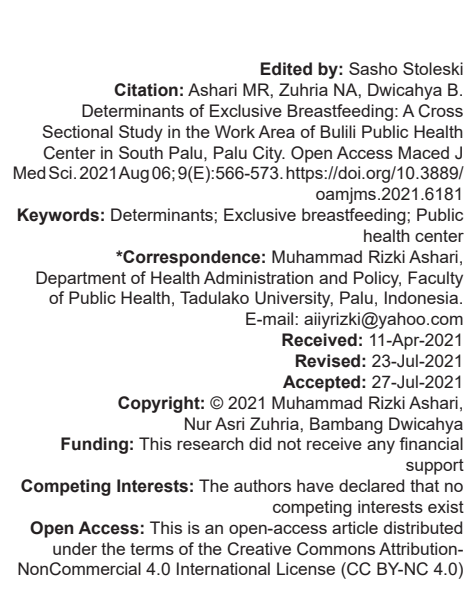

\section{Introduction}

Sustainable development goals (SDGs) are a continuation of the global goal, the Millennium development goals which ended in 2015. One of the targets of SDGs to be achieved is to reduce child mortality with an indicator of decreasing Infant Mortality Rate to $12 / 1000$ live births in 2030 . One effort that can be done to reduce the mortality rate of babies is by giving exclusive breastfeeding [1].

Exclusive breastfeeding in Indonesia is regulated in Government Regulation No. 33 of 2012, implying that exclusive breastfeeding program is held in health care facilities, and health workers are required to provide education and information related to exclusive breastfeeding to mothers and family members of the babies through counseling and mentoring since pregnancy until the exclusive breastfeeding period is over [2].

\begin{abstract}
BACKGROUND: Breastfeeding has an important role in maintaining the health and survival of babies because when they are exclusively breastfed, they will have a good immune system compared to babies who are not exclusively breastfed. Exclusive breastfeeding in Indonesia is regulated in Government Regulation Number 33 of without being added or replaced with other foods/drinks. This is emphasized in Article 6 of Government Regulation breastfeed, or the mother is separate from the baby. Data from the Palu City Health Office shows that the lowest AIM: The aim of this study is to find out the Determinants of Exclusive Breastfeeding in the work area of Bulili Public

(1) ALS ANDODS: This research used a quantitative method with cross-sectional study approach, and simple random sampling method. The population in this study was all mothers who had babies aged 0-6 months with support, health workers support, and policy.

S: Data were analyzed using univariate and bivariate analysis. Chi-square test results summarizes the
\end{abstract}

CONCLUSION: Mother's occupation and formula milk promotion are not related to exclusive breastfeeding, while variables such as supports from families, health workers, and policy are related to exclusive breastfeeding
Based on data from the Health Profile of the Republic of Indonesia in 2018, the coverage of exclusive breastfeeding in Indonesia is $68.74 \%$, exceeding the 2018 strategic plan target of $47 \%$. The region with the highest exclusive breastfeeding coverage was West Java, accounting for $90.79 \%$ in 2018 , while the region with the lowest exclusive breastfeeding coverage was Gorontalo with percentage of $30.71 \%$. Six provinces in Indonesia have not achieved the 2018 Strategic Plan target, including DKI Jakarta, Central Java, Banten, North Sulawesi, Riau, and Gorontalo, while nine provinces have not submitted their data, such as Riau Islands, Bangka Belitung Islands, Papua, South Sumatra, South Kalimantan, North Sumatra, Central Sulawesi, Maluku, and West Papua [3].

On average, the percentage of exclusive breastfeeding coverage in Central Sulawesi Province from 2017 to 2018 experienced insignificant upward trend from year to year, showing an increase from $56.6 \%$ 
in 2017 to $57.7 \%$ in 2018. Based on district/city program manager reports in 2018 the highest average coverage was in Parigi Moutong Regency (80.1\%), compared to 2017 , in which the highest percentage of coverage for infants who were given exclusive breastfeeding was in Banggai Laut Regency (77.7\%). The lowest coverage of infants who received exclusive breastfeeding was in Banggai Islands District (40.6\%) and Toli-toli District $(50.8 \%)$ in 2017, while in 2018 the lowest coverage percentage was in Buol District (39.5\%), and North Morowali Regency (43.8\%) [4].

Based on data from Palu City Public Health Office in 2019, exclusive breastfeeding coverage in the last 3 years experienced fluctuating data trends. In the past 3 years, Exclusive breastfeeding coverage reached $58.0 \%, 59.9 \%$, and decreased back to $58.8 \%$ in 2017, 2018, and 2019, respectively. This coverage has not reached the target of $80 \%$ minimum service standard for National Exclusive Breastfeeding. The highest coverage of exclusive breastfeeding is in the Work Area of Sangurara Public Health Center with the percentage of $75.31 \%$. While the lowest coverage of exclusive breastfeeding in 2019 was in Bulili Public Health Center with the percentage of $37.17 \%$ [5].

Bulili Public Health Center is one of the public health centers in Palu City. The Work Area of Bulili Public Health Center consists of two sub-districts, they are Petobo Village and South Birobuli Village. Based on data in 2017, the Exclusive Breastfeeding coverage of Bulili Public Health Center managed to reach $38.33 \%$, and in 2018, there was a decrease in exclusive breastfeeding from the previous year to $36.25 \%$, and in 2019 increased to (37.17\%). So it can be seen that the exclusive breastfeeding coverage at Bulili Public Health Center is still low and has fluctuated in the past 3 years. The achievement of exclusive breastfeeding at Bulili Public Health Center has not reached the target of $80 \%$ minimum service standard for National Exclusive Breastfeeding coverage [6].

The low exclusive breastfeeding coverage can be affected by maternal work. Because mothers are busy at work, it is an excuse for mothers not to give breast milk to babies so exclusive breastfeeding does not work as it should. Verbally, support for breastfeeding in Work Area is still low. Simple steps that can be done to help increase exclusive breastfeeding are including lactation rooms and breastfeeding breaks. According to Government Regulation No. 33 of 2012 concerning Breastfeeding Article 30, companies must provide support for exclusive breastfeeding programs and provide private lactation areas in the Work Area. The Indonesian Minister of Health has issued Regulation No. 15 of 2013 concerning procedures for providing private lactation areas, but not all businesses or entrepreneurs provide comfortable lactation rooms according to the Government Regulations [7].

Based on the background above, the formulation of the problem of this study was to find out the relationship between maternal work, formula milk promotion, family support, health workers' support, and policy towards exclusive breastfeeding in the Work Area of Bulili Public Health Center in 2020.

\section{Materials and Methods}

The type of research used in this study was a quantitative method with cross-sectional study approach. The subjects in this study were mothers who had babies aged 0-6 months. The sample technique in this study was Simple Random Sampling. Total sample was 103 respondents. The sample inclusion criteria in this study constituted mothers who had babies 0-6 months, mothers who lived in the work area of the Bulili Community Health Center, and mothers who were willing to be respondents. While the exclusion criteria in this study were mothers who had babies more than 6 months, mothers who did not live in the work area of the Bulili Community Health Center, and mothers who were not willing to be respondents. This research was conducted at Bulili Public Health Center of Palu City. Data collection was carried out using a questionnaire using a Likert scale for the variable of exclusive breastfeeding and the Guttman scale for the variables of maternal employment status, family support, health workers support, and policy. The questionnaire in this study was tested for validity and reliability before distribution. Data analysis used univariate analysis and bivariate analysis.

\section{Results}

\section{Univariate analysis}

Univariate analysis aims to obtain a description of the distribution or the proportion of variables under study using frequency distribution of each of the variables studied, including both independent and dependent variables.

Table 1: Characteristics of respondents in the work area of UPTD Bulili Public Health Center

\begin{tabular}{lll}
\hline Characteristics & Frequency & Percentage \\
\hline Age & 13 & \\
$18-20$ & 21 & 12.6 \\
$21-23$ & 41 & 20.4 \\
$24-26$ & 9 & 89.8 \\
$27-29$ & 8 & 7.8 \\
$30-32$ & 8 & 7.8 \\
$33-35$ & 3 & 2.9 \\
$36-38$ & & \\
Education & 5 & 4.9 \\
Elementary School & 10 & 9.7 \\
Middle School & 71 & 68.9 \\
High School & 17 & 16.5 \\
University & &
\end{tabular}

Based on Table 1, the majority of respondents who were sampled in this study were aged 24-26 years 
old of 41 respondents $(39.8 \%)$, with high school education as majority of 71 respondents $(68.9 \%)$.

Table 2: Distribution of respondents based on employment status in the work area of UPTD Bulili Public Health Center

\begin{tabular}{lll}
\hline Job & Frequency & Percentage \\
\hline Unemployed (URT) & 80 & 77.7 \\
Entrepreneur & 20 & 19.4 \\
Non-permanent & 3 & 2.9 \\
Total & 103 & 100.0 \\
\hline Source: Primary Data 2020. & &
\end{tabular}

Based on Table 2, it shows that out of 103 respondents, respondents with unemployed status (URT) had the highest number of 80 people $(77.7 \%)$ while the lowest was non-permanent of 3 people $(2.9 \%)$.

Table 3: Distribution of respondents based on exclusive breastfeeding in the work area of UPTD Bulili Public Health Center

\begin{tabular}{lll}
\hline Exclusive Breastfeeding & Frequency & Percentage \\
\hline Exclusive & 25 & 24.3 \\
Not Exclusive & 78 & 75.7 \\
Total & 103 & 100.0 \\
\hline Source: Primary Data 2020. & &
\end{tabular}

Based on Table 3, it shows that out of 103 respondents, 25 respondents $(24.3 \%)$ gave exclusive breastfeeding, while 78 respondents $(75.7 \%)$ did not give exclusive breastfeeding.

Based on Table 4, it shows that out of 103 respondents, respondents who were interested in formula milk promotion were 35 people $(34.0 \%)$ while respondents who were less interested were 68 people $(66.0 \%)$.

Table 4: Distribution of respondents based on formula milk promotion in the work area of UPTD Bulili Public Health Center

\begin{tabular}{lll}
\hline Formula Milk Promotion & Frequency & Percentage \\
\hline Interested & 35 & 34.0 \\
Less Interested & 68 & 66.0 \\
Total & 103 & 100.0 \\
\hline Source: Primary Data 2020. & &
\end{tabular}

Based on Table 5, it shows that out of 103 respondents, there were 49 respondents (47.6\%) who received full support from their families while 54 people $(52.4 \%)$ had less support.

Table 5: Distribution of respondents based on family support in the work area of UPTD Bulili Public Health Center

\begin{tabular}{lll}
\hline Family Support & Frequency & Percentage \\
\hline Full support & 49 & 47.6 \\
Less support & 54 & 52.4 \\
Total & 103 & 100.0 \\
\hline Source: Primary Data 2020. & &
\end{tabular}

Based on Table 6, it shows that out of 103 respondents, there were 101 respondents who received full support from health workers (98.1\%) while the respondents who received less support were 2 people (1.9\%)

Based on Table 7, it shows that out of 103 respondents, 78 respondents $(75.7 \%)$ agreed with the policy of exclusive breastfeeding, while 25 respondents

Table 6: Distribution of respondents based on health workers support in the work area of UPTD Bulili Public Health Center

\begin{tabular}{lll}
\hline Health Workers Support & Frequency & Percentage \\
\hline Full support & 101 & 98.1 \\
Less support & 2 & 1.9 \\
Total & 103 & 100.0 \\
\hline Source: Primary Data 2020. & &
\end{tabular}

$(24.3 \%)$ disagreed with the policy of exclusive breastfeeding.

Table 7: Distribution of respondents based on policy in the work area of UPTD Bulili Public Health Center

\begin{tabular}{lll}
\hline Policy & Frequency & Percentage \\
\hline Agree & 78 & 75.7 \\
Disagree & 25 & 24.3 \\
Total & 103 & 100.0 \\
\hline Source: Primary Data 2020 & &
\end{tabular}

\section{Bivariate analysis}

Bivariate analysis aims to determine the relationship between independent variable and dependent variable.

Based on the results in Table 8, there are 23 respondents $(22.3 \%)$ who have the status of working mothers, 16 people (15.5\%) did not exclusively breastfeed their babies, and 7 people $(6,8 \%)$ did. Meanwhile, 80 respondents $(77.7 \%)$ did not have the status of working mothers, 62 people $(60.2 \%)$ did not exclusively breastfeed their babies, and 18 people $(17.5 \%)$ did.

Table 8: Distribution of respondents based on the relationship between employment status and exclusive breastfeeding in the work area of Bulili Public Health Center, Palu City

\begin{tabular}{|c|c|c|c|c|c|c|c|}
\hline \multirow{3}{*}{$\begin{array}{l}\text { Employment } \\
\text { Status }\end{array}$} & \multicolumn{4}{|c|}{ Exclusive Breastfeeding } & \multirow{2}{*}{\multicolumn{2}{|c|}{ Total }} & \multirow[t]{3}{*}{$\mathrm{p}$} \\
\hline & \multicolumn{2}{|c|}{ Not Exclusive } & \multicolumn{2}{|c|}{ Exclusive } & & & \\
\hline & $\mathrm{n}$ & $\%$ & $\mathrm{n}$ & $\%$ & $\mathrm{n}$ & $\%$ & \\
\hline Working & 16 & 15.5 & 7 & 6.8 & 23 & 22.3 & 0.434 \\
\hline Not Working & 62 & 60.2 & 18 & 17.5 & 80 & 77.7 & \\
\hline Total & 78 & 75.7 & 25 & 24.3 & 103 & 100 & \\
\hline
\end{tabular}

Based on the results of the analysis using Chisquare test, the results were $p=0,434$, so $p>0.05$, then $\mathrm{H}_{0}$ in this study was accepted and $\mathrm{H}_{\mathrm{a}}$ was rejected, which means that there is no relationship between employment status and exclusive breastfeeding variables in the Work Area of Bulili Public Health Center.

Based on the results in Table 9, there were 68 respondents $(66.0 \%)$ who were less interested in formula milk promotion, 47 people (45.6) did not exclusively breastfeed their babies and 21 people (20.4\%) did. While 35 respondents $(34.0 \%)$ who were interested in formula milk promotion, 4 people $(3.9 \%)$ did not exclusively breastfeed their babies and 31 people (30.1\%) did.

Based on the results of the analysis using Chisquare test, it was obtained that $p=0.029$, so $p<0.05$, then $\mathrm{H}_{0}$ in this study was rejected and $\mathrm{H}_{\mathrm{a}}$ was accepted, which means that there is a relationship between formula milk promotion and exclusive breastfeeding

Table 9: Distribution of respondents based on the relationship between formula milk promotion and exclusive breastfeeding in the work area of Bulili Public Health Center, Palu City

\begin{tabular}{|c|c|c|c|c|c|c|c|}
\hline \multirow{3}{*}{$\begin{array}{l}\text { Employment } \\
\text { status }\end{array}$} & \multicolumn{4}{|c|}{ Exclusive breastfeeding } & \multirow{2}{*}{\multicolumn{2}{|c|}{ Total }} & \multirow[t]{3}{*}{$\mathrm{p}$} \\
\hline & \multicolumn{2}{|c|}{ Not exclusive } & \multicolumn{2}{|c|}{ Exclusive } & & & \\
\hline & $\mathrm{n}$ & $\%$ & $\mathrm{n}$ & $\%$ & $\mathrm{n}$ & $\%$ & \\
\hline Less & 47 & 45.6 & 21 & 20.4 & 68 & 66 & 0.029 \\
\hline Interested & & & & & & & \\
\hline Interested & 4 & 3.9 & 31 & 30.1 & 35 & 34 & \\
\hline Total & 78 & 75.7 & 25 & 24.3 & 103 & 100 & \\
\hline
\end{tabular}


variables in the Work Area of Bulili Public Health Center.

Based on the results in Table 10, there were 2 respondents $(1.9 \%)$ who received less support from health workers, 2 people (1.9\%) did not exclusively breastfeed their babies. While 101 respondents (98.1\%) received full support from health workers, 76 people $(73.8 \%)$ did not exclusively breastfeed their babies and 25 people $(24.5 \%)$ did.

Table 10: Distribution of respondents based on the relationship between family support and exclusive breastfeeding in the work area of Bulili Public Health Center, Palu City

\begin{tabular}{|c|c|c|c|c|c|c|c|}
\hline \multirow{3}{*}{$\begin{array}{l}\text { Health workers } \\
\text { support }\end{array}$} & \multicolumn{4}{|c|}{ Exclusive breastfeeding } & \multirow{2}{*}{\multicolumn{2}{|c|}{ Total }} & \multirow[t]{3}{*}{$\mathrm{p}$} \\
\hline & \multicolumn{2}{|c|}{ Not exclusive } & \multicolumn{2}{|c|}{ Exclusive } & & & \\
\hline & $\mathrm{n}$ & $\%$ & $\mathrm{n}$ & $\%$ & $\mathrm{n}$ & $\%$ & \\
\hline Less support & 2 & 1.9 & 0 & 0.0 & 2 & 1.9 & 0.572 \\
\hline Full support & 76 & 73.8 & 25 & 24.5 & 101 & 98.1 & \\
\hline Total & 78 & 75.7 & 25 & 24.3 & 103 & 100 & \\
\hline
\end{tabular}

The results of the analysis using Chi-square test,show that $p=0.572$ so $p>0.05$, then $H_{0}$ in this study was accepted and $\mathrm{H}_{\mathrm{a}}$ was rejected, which means that there is no relationship between health workers support and exclusive breastfeeding variables in the Work Area of Bulili Public Health Center.

From Table 11 it can be seen that out of 25 respondents $(24.3 \%)$ who disagreed with exclusive breastfeeding policy, 25 people (24.3\%) did not exclusivelybreastfeed theirbabies. While 78 respondents $(75.7 \%)$ agreed with exclusive breastfeeding policy, 53 people $(51.5 \%)$ did not exclusively breastfeed their babies and 25 people (24.3\%) did.

Table 11: Distribution of respondents based on the relationship between policy and exclusive breastfeeding in the work area of Bulili Public Health Center, Palu City

\begin{tabular}{|c|c|c|c|c|c|c|c|}
\hline \multirow[t]{3}{*}{ Policy } & \multicolumn{4}{|c|}{ Exclusive breastfeeding } & \multirow{2}{*}{\multicolumn{2}{|c|}{ Total }} & \multirow[t]{3}{*}{$\mathrm{p}$} \\
\hline & \multicolumn{2}{|c|}{ Not exclusive } & \multicolumn{2}{|c|}{ Exclusive } & & & \\
\hline & $\mathrm{n}$ & $\%$ & $\mathrm{n}$ & $\%$ & $\mathrm{n}$ & $\%$ & \\
\hline Disagree & 25 & 24.3 & 0 & 0.0 & 25 & 24.3 & 0.001 \\
\hline Agree & 53 & 51.5 & 25 & 24.3 & 78 & 75.7 & \\
\hline Total & 78 & 75.7 & 25 & 24.3 & 103 & 100 & \\
\hline
\end{tabular}

The results of the analysis using Chi-square test showed $p=0.001$ so $p<0.05$, then $\mathrm{H}_{0}$ in this study was rejected and $\mathrm{H}_{\mathrm{a}}$ was accepted, which means that there is a relationship between policy and exclusive breastfeeding variables in the Work Area of Bulili Public Health Center.

\section{Discussion}

\section{Relationship between mother's employment status and exclusive breastfeeding}

Work is an activity that someone does every day to earn money to meet their needs [8]. Based on the results of the study, there were respondents who worked and still provide exclusive breastfeeding. This is because the mothers give their exclusive breastfeeding indirectly by milking it first before doing activities outside which takes a lot of time. This is in line with Timporok's study which stated the importance of exclusive breastfeeding for babies so work should not become an excuse for mothers from not giving exclusive breastfeeding to their babies. One of the efforts that can be made in order to continue providing exclusive breastfeeding to babies is by milking the breast milk. Mothers can milk the breast milk properly so the benefits are not reduced [9].

Meanwhile, based on the results of the study, the majority of respondents did not work and did not provide exclusive breastfeeding to their babies. This is due to several conditions experienced by mothers such as swelling in the breasts that caused pain, breast milk that do not come out, and the condition where the mothers' nipples do not come out at the early stage of birth so mothers choose to give formula milk instead. This is in line with Rayhana's study which implies that breast care is very important because breast care is useful for increasing milk production, can flex and strengthen the nipples so it will be easier for the babies to breastfeed on their mother. The mothers' good habits in carrying out breast care will have a good impact on the continuity of breast milk. On the other hand, mothers who do not do breast care will have a negative impact on the adequacy of breast milk for their babies [10].

The results of the analysis using Chi-square test, show that $p=0.434$, so $p>0.05$, which means that there is no relationship between maternal employment status and exclusive breastfeeding variables. This is because mothers who do not work have more time with their babies than mothers who have jobs outside the home, so mothers who do not work can focus more on achieving the success of exclusive breastfeeding.

While this study is in line with the study conducted by Bahryah stating that mothers who do not work have a lot of time with their babies, so the opportunity to exclusively breastfeed their babies is greater than that of mothers who work outside [11]. This study is not in line with the study conducted by Ramli, stating that mothers as housewives do not provide exclusive breastfeeding to their babies. Mothers who work outside have great relationships and opportunities to get information [12].

\section{Relationship between formula milk promotion and exclusive breastfeeding}

Formula milk promotion is a series of activities carried out by producers or manufacturers to inform the benefits of formula milk products as a substitute for exclusive breastfeeding which aims to persuade consumers to feel that consumers need formula milk from the company [13].

Based on the results of the study, respondents were less interested in formula milk promotion, but did not provide exclusive breastfeeding to their babies 
due to several factors, such as mothers' knowledge about breast milk. This is in line with Rambi, stating that mothers' ignorance about exclusive breastfeeding is an inhibiting factor for the development of parental awareness about the importance of exclusive breastfeeding [14].

Meanwhile, there were respondents who were interested in formula milk promotion and continue to provide exclusive breastfeeding to their babies. This is because mothers see formula milk advertisements in various electronic media and mothers have knowledge about breast milk. This is in line with Wahyuni, who stated that mothers who receive formula milk promotion and know about the benefits of breastfeeding will assess what they know, then exclusive breastfeeding will emerge [15]

The Chi-square test, also shows that $p=0.026$, so $p<0.05$, meaning that there is a relationship between formula milk promotion and exclusive breastfeeding variables. This is because mothers have seen formula milk advertisements in electronic media when they are pregnant and have babies aged $<6$ months and the mothers have been offered formula milk before their babies are $<6$ months old. This is in line with the study by Wahyuni, implying that there is a relationship between the formula milk promotion and exclusive breastfeeding, because a promotional activity can influence people's behavior to know and understand a product, so someone who receives a promotion has the desire or interest to try and buy the product [13].

Meanwhile, this study is not in line with the study of Oktova, where the $p$-value shows $0.573>0$ 0.05 . This means that there is no relationship between formula milk promotion and exclusive breastfeeding for infants aged 0-6 months. Mothers Giving give formula milk to their babies, believing that whatever mothers give to their babies is the right step for the health and well being of their children [15].

\section{Relationship between family support and exclusive breastfeeding}

Act No. 52 of 2009 concerning population development and family development states that family is the smallest unit in society consisting of husband and wife, or husband, wife and children, or a father and a child, or a mother and a child. Family support is a process that occurs in everyone's life, which has different characteristics and types of support so it can affect someone's behavior [8].

Based on the results of the study, respondents received less support from their families and did not provide exclusive breastfeeding for their babies. This is because the families do not provide information and do not recommend mothers to continue exclusive breastfeeding until the babies are 6 months old. Lack of attention to the mothers' health conditions at the early period of birth can cause mothers to make the decisions to give formula milk to their babies.

This is in line with Indarwati who stated that the success of mothers in breastfeeding is the result of teamwork between mothers, babies, fathers and families. Difficulty in breastfeeding usually occurs within the first 10-14 days after delivery because the mothers' breasts begin to swell, the nipples are chafed, the babies are fussy and do not want to breastfeed, all often resulting in early discontinuation of. This is where the important roles of the husbands (babies' fathers) and families are needed. With the support of husband and family, exclusive breastfeeding can work well [17].

Meanwhile, based on the results of the study the respondents received full family support and continue to provide exclusive breastfeeding for their babies. This is because mothers get information about the importance of exclusive breastfeeding and the families encourage mothers to exclusively breastfeed their babies. So mothers become enthusiastic and always provide exclusive breastfeeding to their babies. This is in accordance with Mamangkey who stated that the greater the support is provided by family to the mother, the greater the influence for the mother will be to maximize exclusive breastfeeding, rather than mothers who receive less family support [18].

The results of the analysis using Chi-square test, show that $p=0.019$, so $p>0.05$, which means there is a relationship between family support and exclusive breastfeeding variables. This is because the families rarely listen to the complaints felt by the mothers, and the mothers rarely get information from their families about how to correctly breastfeed their babies; they do not remind the mothers to always give exclusive breastfeeding to the babies until they are 6 months old, the mothers do not get enough praise when the mothers finish breastfeeding and the family members are not helping the mothers when providing baby equipment.

This is in line with the statement implying that achieving exclusive breastfeeding for 6 months requires knowledge and motivation from mothers. By having sufficient knowledge and motivation, mothers will continue and try to breastfeed their babies and know what can be obtained by breastfeeding the babies, so it will have an impact on the emergence of motivation in breastfeeding. Besides arising from knowledge about breastfeeding, family support is the external factor that has the greatest influence on the success of exclusive breastfeeding. With the support from families, especially from the husbands, it will have an impact on increasing self-confidence or motivation of the mothers in breastfeeding [18].

Meanwhile, this study is not in line with the study by Elliana, who stated that there is no relationship between family support and exclusive breastfeeding. Breastfeeding is less influenced by behavior in exclusive breastfeeding, where one's behavior towards 
health objects, whether there is support from family or society, information obtained and situations that allow mothers to make decisions to provide complementary foods as soon as possible or not that have an impact on complementary feeding [19].

\section{Relationship between health workers support and exclusive breastfeeding}

Health workers' support is a factor associated with exclusive breastfeeding. Physical and psychological comfort, training, and rewards, which are received by individuals and provided by health workers can realize emotional support, mental support, reward and information on exclusive breastfeeding [20].

Based on the results of the study, respondents did not receive support from health workers and did not provide exclusive breastfeeding to their babies. It is because mothers rarely visit health services so they do not receive information about exclusive breastfeeding for their babies.

This is in line with Ransum (2018), which shows that there is no relationship between health workers' support and exclusive breastfeeding, which shows value of $p=0.807(>0.005)$. Lack of support from health workers causes the failure of exclusive breastfeeding. Health workers do not only provide information and education about breastfeeding, but also take concrete actions, by not providing any milk assistance without any specific indication [21].

Many respondents received full support from health workers and continue to provide exclusive breastfeeding for their babies. This is because when mothers visit health centers or other health services, mothers always get information about exclusive breastfeeding either through counseling or personal education, and mothers are always reminded to provide exclusive breastfeeding for their babies until they are 6 months old. This is not in line with the study conducted by Zuhrotunida (2017) stating that mothers who receive support from health workers have 9 times greater chance of giving exclusive breastfeeding than mothers who do not [22].

Results of the analysis using Chi-square test, show that $p=0.572$, so $p>0.05$ which means there is no relationship between health workers' support and exclusive breastfeeding variables. This is because most mothers receive support from health workers. Mothers always get information about proper and correct breastfeeding procedures, health workers often advise mothers to provide exclusive breastfeeding until their babies reach 6 months old, health workers recommend that they always eat nutritious food and almost all respondents feel comfortable with health workers.

This is in line with the study conducted by Vani (2018). The results of Chi-square value obtained $p=1.000$ which is $>\alpha=0.05$, which means that there is no significant relationship between health workers support and exclusive breastfeeding. This is because the mothers' decision whether to breastfeed or not is not due to the support from health workers, but rather external factors, such as the mothers' attitude and behavior [22].

Meanwhile, this research is also not in line with Yulidasari (2017), stating that there is a relationship between health workers support and the practice of exclusive breastfeeding. Health workers support plays a very important role in exclusive breastfeeding because if health workers often provide information and educational counseling about exclusive breastfeeding, mothers who have babies will breastfeed their babies [23].

\section{Relationship between policy and exclusive breastfeeding}

Success in implementing exclusive breastfeeding programs needs to be supported by policies from both the central and local governments [24].

In Article 128 paragraphs (1), (2), and (3) Act No. 36 of 2009 concerning Health, it is formulated that: (1) Every baby has the right to receive exclusive breast milk from birth for 6 months, except for medical indications. (2) During breastfeeding, families, Government, local governments and the community must fully support the mothers by providing special time and facilities. (3) The special facilities as meant in paragraph (2) are provided at Work Areas and public facilities [25].

Based on the results of the study, several respondents did not comply with exclusive breastfeeding policy and did not provide exclusive breastfeeding to their babies because some mothers do not agree that exclusive breastfeeding is given for 6 months without providing any foods or drinks. And babies whose mothers are medically indicated or those who are separated from their mothers must continue to receive exclusive breastfeeding for up to 6 months. This is because some mothers do not know that there is an exclusive breastfeeding policy that has been set by Indonesian government so the fulfillment of children's rights can be achieved.

This is in line with the study by Zainafree (2016) which stated that the main responsibility for children's welfare rights lies with parents. Meanwhile, the country has an obligation to ensure that parents have really fulfilled these responsibilities or obligations [25]

Meanwhile, respondents agreed with the policy of giving exclusive breastfeeding and continue to provide exclusive breastfeeding to their babies because they know the importance of exclusive breastfeeding and are aware that exclusive breastfeeding is a right that must be fulfilled by a mother to her child. This is in 
line with the study conducted by Nurdiana implying that the higher level of mothers' knowledge is, the greater the willingness and awareness of the mothers will be to breastfeed their babies exclusively. Conversely, the lower level of mothers' knowledge is, the less the willingness and awareness of the mothers will be to breastfeed their babies exclusively. Knowledge is the basis for the formation of health behavior [26].

The occurrence of a behavior change is explained by Lawrence Green in Notoatmodjo (2012), implying that human behavior from the health level of a person or society is formed by three factors, one of which is reinforcing factor,that provides support for behavior. The support provided can be in the form of positive support. This factor includes policy [27].

Many relatively inexpensive and easy measures can be implemented to improve the health and survival of children, especially newborns. One of them is breastfeeding immediately after birth or commonly known as Early Initiation of Breastfeeding as well as exclusive breastfeeding until the age of 6 months. This is supported by the statement of United Nations Children Funds implying that 30.000 infant deaths in Indonesia and 10 million deaths of children under five in the world each year can be prevented through exclusive breastfeeding for 6 months from the birth, without having to provide additional foods and drinks for babies [25].

\section{Conclusion}

Mother's employment status is not related with exclusive breastfeeding. This is because mothers who do not work have more time with their babies than mothers who have jobs outside the home so that mothers who do not work can focus more on achieving success in exclusive breastfeeding. Meanwhile, formula milk promotion variable is also not related to exclusive breastfeeding because mothers have seen formula milk advertisements in electronic media during pregnancy and have babies $<6$ months and the mothers have been given formula milk before the babies $<6$ months.

Family support is related to exclusive breastfeeding. The reason is families do not provide information and do not recommend the mothers to continue giving exclusive breastfeeding until the babies are 6 months old. Lack of attention to the health condition of the mothers in the early stages of labor can cause the mothers to make the decision to give formula milk to their babies. Meanwhile, health workers' support is also related to exclusive breastfeeding, because mothers who rarely seek treatment do not get information about the benefits of exclusive breastfeeding for their babies.
Policy is also related to exclusive breastfeeding. The reason is that some mothers do not know about the exclusive breastfeeding policy that has been established by the Indonesian government so that the fulfillment of children's rights can not be achieved.

The limitation in this research is the time of the research which causes the researcher to only be able to examine in terms of mothers' employment status, promotion of formula milk, family support, support of health workers, and policies. Meanwhile, there are other factors that also influence exclusive breastfeeding but were not investigated in this study such as age, knowledge, lactation management, maternal and infant health status, education attitudes, mothers, values, and beliefs.

\section{References}

1. Wahyuningsih W. Millennium development goals (MDGS) and sustainable development goals (SDGS) in BISMA. BISMA. 2017;11(3):390-9. https://doi.org/10.19184/bisma.v11i3.6479

2. Wismantari M. Analysis of the input and environment of breastfeeding mothers on the exclusive breastfeeding program. J Kesehatan Masyarakat. 2018;6(5):117-23. https://doi. org/10.31965/infokes.vol16.iss2.222

3. Kementerian Kesehatan RI. Profil Kesehatan Indonesia 2018. Indonesia: Kementerian Kesehatan RI; 2018. https://doi. org/10.33560/jmiki.v8i1.257

4. Dinas Kesehatan Provinsi Sulawesi Tengah. Profil Kesehatan Provinsi Sulawesi Tengah Tahun 2018. Vol. 1. Indonesia: Profil Kesehat Provinsi Sulawesi Teng Tahun; 2018. p. 1-5. https://doi. org/10.31227/osf.io/xdhk9

5. Dinkes. Profil Kesehatan Kota Palu 2019; 2019.

6. Profil Puskesmas Bulili Tahun 2018; 2018.

7. Sari Y. Lack of exclusive breastfeeding among working mothers in Indonesia. Kesmas. 2016;11(2):61-8. https://doi. org/10.21109/kesmas.v11i2.767

8. Hertanto E. Factors associated with early complementary feeding. J Kesehat. 2017;2:141-52. https://doi.org/10.30604/ jika.v2i2.56

9. Aga T. The relationship between maternal employment status and exclusive breastfeeding in the working area of the kawangkoan health center. J Keperawatan. 2018;6(1):1-6. https://doi.org/10.34012/jukep.v3i1.798

10. Rayhana. Kecukupan Asi The Factors Influencing Breast Milk Production With; 2017

11. Bahriyah F, Putri M, Jaelani Ak, Indragiri AK. The relationship between mother's work and exclusive breastfeeding for babies. J Endurance. 2017;2(2):113-8. https://doi.org/10.22216/jen. v2i2.1699

12. Ramli R. Correlation of mothers' knowledge and employment status with exclusive breastfeeding in sidotopo. J Promkes. 2020;8(1):36. https://doi.org/10.20473/jpk.v8.i1.2020.36-46

13. Yumni FL, Wahyuni CT. The relationship between formula milk advertising promotion and exclusive breastfeeding in Pandanarum Village, Pacit District, Mojokerto Regency. J Keperawatan Muhammadiyah. 2018;3(2):95-100. https://doi. org/10.30651/jkm.v3i2.1779

14. Rambi CA, Patras MD, Umboh MJ. Faktor-Faktor Yang 
Berhubungan Dengan Tindakan Pemberian Asi Eksklusif di Wilayah Kerja Puskesmas Kendahe Kabupaten Kepulauan Sangihe Sulawesi Utara; 2015. p. 66-80. https://doi. org/10.33757/jik.v1i1.21

15. Oktova R. Analysis of factors related to formula feeding in infants 0-6 months. J Kesehat. 2017;8(3):315. https://doi.org/10.26630/ jk.v8i3.503

16. Al Indarwati ET. Factors associated with exclusive breastfeeding to the mother. J Obs J Pendidik Anak Usia Dini. 2017;2(1):130. https://doi.org/10.31004/obsesi.v2i1.17

17. Hanifah SA, Astuti S, Susanti Al. Description of the characteristics of breastfeeding mothers who do not provide exclusive breastfeeding in Cikeruh Village, Jatinangor District, Sumedang Regency in 2015. J Sist Kesehat. 2017;3(1):38-43. https://doi.org/10.24198/jsk.v3i1.13960

18. Mamangkey SJ. Relationship between family support and exclusive breastfeeding for babies at the Ranotana Weru Public Health Center. J Keperaw. 2018;6:1-6. https://doi.org/10.30736/ midpro.v8i1.2

19. Elliana D. The relationship between knowledge and family support about exclusive breastfeeding with exclusive breastfeeding in the working area of the puskesmas now in the city of Semarang. J Kebidanan. 2018;7(2):135-43. https://doi. org/10.26714/jk.7.2.2018.135-143

20. Wati LR, Arifiandi MD, Prastiwi F. The effect of the support of health workers on exclusive breastfeeding in the working area of the Sisir Puskesmas, Sisir Village, Batu City. J Issues Midwifery.
2017;1:1-18. https://doi.org/10.21776/ub.joim.2017.001.02.3

21. Zuhrotunida SS, Zuhrotunida MK. The relationship between health care workers and the success of exclusive breastfeeding at the Kutabumi Public Health Center. Indones Midwifery J. 2018;1:2

22. Vani JD. The relationship between education and support of health workers with exclusive breastfeeding at the Palembang Merdeka Health Center in 2018. J Keperawatan. 2018;5(6):7997. https://doi.org/10.33757/jik.v2i2.133

23. Yulidasari F. Health workers support, Culture and status of exclusive breastfeeding in sungai ulin community health center. J Unnes. 2017;13(1):7-12. https://doi.org/10.15294/kemas. v13i1.6557

24. DewiA, Suparwati A, Suryawati C. Analysis of the implementation of the exclusive breastfeeding policy at the district level in Kebumen in 2013. J Kesehat Masy. 2014;2:22-7.

25. Zainafree I, Widanti SE. The policy of exclusive breastfeeding and child welfare in realizing children's rights. Soepra J Huk Kesehat. 2016;2(1):74-90. https://doi.org/10.24167/shk. v2i1.811

26. Nurdiana I. Fakultas IImu Kesehatan Universitas Muhammadiyah Surakarta, E-Journal; 2015.

27. Pebriyani $U$, Alfarisi R, Putri $G H$, Kunci K. Hubungan Tingkat Pengetahuan Ibu Tentang Ispa Dengan Perilaku Pencegahan Pada Balita di Wilayah Kerja Puskesmas Pasar Ambon Bandar Lampung Tahun 2016; 2015. https://doi.org/10.33086/jhs. v10i1.146

Author Queries???

AQ3: Kindly cite the references 16 in the text part 